\begin{tabular}{lc}
\hline & ANNALES \\
& UNIVERSITATIS MARIAE CURIE-SKŁODOWSKA \\
LOL. V & SECTIO N \\
\hline
\end{tabular}

ISSN: 2451-0491 • e-ISSN: 2543-9340 • CC-BY 4.0 • DOI: 10.17951/en.2020.5.131-147

\title{
Multimedialny moduł tematyczny (MMT), czyli o głośnym czytaniu jako aksjologicznej edukacji na lekcjach polskiego w szkole średniej
}

\section{Multimedia Theme System (MTS), or about Reading Aloud as Axiological Education in Polish Lessons in High School}

\author{
Elżbieta Kotarba \\ Zespół Szkół - Małopolska Szkoła Gościnności w Myślenicach \\ ul. Zdrojowa 18, 32-400 Myślenice, Polska \\ kotarba.elzbieta@gmail.com \\ http://orcid.org/0000-000209747-8443
}

\begin{abstract}
The task of humanistics, including didactics of the Polish language, is a meeting with literary work. This is a difficult task, especially nowadays when electronic media has become the main carriers of values and pseudo-values. The author presents the results of the research based on the value of reading after the lessons about Sophocles' King Oedipus as part of the curriculum of multimedia thematic modules. Reading has turned out to be an irreplaceable benefit in the face of the growing reluctance of young people to discuss difficult and demanding reading material in Polish language lessons.
\end{abstract}

Keywords: humanistics; didactics of the Polish language; literary work; multimedia thematic modules

Abstrakt. Zadaniem humanistyki, w tym dydaktyki języka polskiego, jest spotkanie z dziełem literackim. To trudne zadanie, szczególnie w dzisiejszych czasach, kiedy media elektroniczne stały się głównymi nośnikami wartości i pseudowartości. Autorka przedstawia wyniki badań na 
temat wartości czytania po przeprowadzeniu lekcji o Królu Edypie Sofoklesa w ramach programu nauczania multimedialnymi modułami tematycznymi. Czytanie okazuje się niezastąpioną wartością w obliczu narastającej niechęci młodych ludzi do omawiania trudnych i wymagających lektur na lekcjach języka polskiego.

Słowa kluczowe: humanistyka; dydaktyka języka polskiego; dzieło literackie; multimedialne moduły tematyczne

\section{CZYTELNICTWO MŁODZIEŻY}

W sytuacji, gdy media elektroniczne stały się głównymi nośnikami wartości i pseudowartości, zadaniem humanistyki, w tym dydaktyki języka polskiego, jest spotkanie z dziełem literackim - „spotkanie prawdziwe, bo oparte na czytaniu dzieła, a nie jego streszczenia [...]" (Kania i Strawa 2015: 199). Celem artykułu nie jest włączanie się w dyskurs na temat kanonu lektur szkolnych. O historii tego sporu pisało wielu autorów (Bortnowski 2007; Dyrda i Gumuła 2009; Janus-Sitarz 2009; Kaniewski 2007; Morawska 2017: 29-44). Niezależnie od tego, jaka jest lub będzie podstawa programowa, ważne jest wykształcenie kultury czytania oraz umiejętności pogłębiania interpretacji tekstów kultury. Joanna Cieloch-Niewiadomska w artykule pod wymownym tytułem Szkoła nieczytania (2015) przedstawia na podstawie ostatnich badań stan czytelnictwa w Polsce oraz wpływ szkoły na kulturę czytania dzieci i młodzieży. Wyniki nie są zadowalające. Jeśli chodzi o przyczyny takiej sytuacji, autorka wskazuje m.in. na środowisko rodzinne, kanon lektur szkolnych oraz podstawę programową. Przede wszystkim jednak stawia tezę, iż młodym ludziom brakuje wartości czytania dla przyjemności. Jedynym sposobem, aby temu przeciwdziałać, jest wykształcenie tej umiejętności w szkole i w domu rodzinnym. Przedstawiając wyniki badań, autorka wymienia korzyści płynące z praktyki szkolnego czytania. Są to m.in. podniesienie poziomu wypowiedzi ustnych i pisemnych, wzrost zrozumienia tekstów i poleceń, poprawa koncentracji, zwiększenie skłonności do refleksji, wypracowanie umiejętności myślenia przyczynowo-skutkowego, nabywanie umiejętności rozwiązywania własnych problemów emocjonalnych, poprawa wzajemnych relacji, większa otwartość na nowe sytuacje i osoby (tamże: 58).

Praktyka szkolnego czytania w czasie lekcji jest często pomijana lub całkowicie niwelowana ze względów praktycznych, zwłaszcza w szkole średniej. Stąd postulat o zwrócenie szczególnej uwagi na kształtowanie czytania jako wartości samej w sobie, nie tylko na lekcjach języka polskiego, lecz także podczas realizacji innych przedmiotów szkolnych.

Głównym środowiskiem wpływającym na dzieci i młodzież jest rodzina. To rodzice i środowisko rodzinne, jak wskazują badania, najlepiej uczą przyjemności 
czytania i podkreślają jego wartość (tamże: 49-50). Często jednak zdarza się, że rodzina nie jest w stanie zrealizować tego postulatu. Wówczas zadaniem szkoły jest szeroko rozumiana edukacja kulturowa, dostosowana do współczesnych realiów szkolnej polonistyki. Dlatego należy zwrócić szczególną uwagę na wartość głośnego czytania podczas lekcji, co wiąże się z kształceniem przyjemności czytania wśród dzieci i młodzieży. Taki postulat wydaje się oczywisty w szkole podstawowej, kiedy pokolenie cyfrowych tubylców ${ }^{1}$ wkracza w świat druku. Jest to często bardzo męczący proces, który wiąże się z bolesnym i mozolnym odczytywaniem dłuższych tekstów literackich. Młodzi ludzie, przyzwyczajeni do kultury obrazkowej, nie radzą sobie z koncentracją przy czytaniu dłuższego tekstu. Wymaga to od nich wysiłku i nie zawsze wiąże się z czymś przyjemnym. Podobne problemy można zauważyć wśród uczniów w szkole średniej. Zdecydowanie wolą oni lekcje, w czasie których wykorzystują nowoczesne technologie cyfrowe, a nie tekst pisany. Większym zainteresowaniem młodych cieszą się zajęcia, na których można obejrzeć film, posłuchać muzyki, rozwiązać test na www.kahoot.it lub poszukać dzieł sztuki w aplikacji Google Maps - Street View².

Formuła matury pisemnej i ustnej z języka polskiego zakłada jednak rozumienie czytanego tekstu oraz wypowiedź pisemną. Abiturient powinien zrozumieć tekst i zinterpretować go w kontekście kulturowym (rozporządzenie Ministra Edukacji Narodowej z dnia 30 stycznia 2018 roku). Takie umiejętności nie stanowią wielkiego wyzwania dla uczniów, którzy od dzieciństwa lubią czytać - dla nich czytanie jest bowiem wartością samą w sobie. Pozostaje więc pytanie: Jak wykształcić wymagane umiejętności wśród osób, które nie rozumieją, czym jest przyjemność czytania?

\section{NAUCZYCIEL I CYFROWY TUBYLEC W ŚRODOWISKU SZKOLNYM}

W liceum i technikum jest trudniej niż w szkole podstawowej zaszczepić młodym ludziom „bakcyla czytania”. Uczniowie przychodzą już z pewnymi nawykami i uprzedzeniami wyniesionymi ze szkoły podstawowej (do niedawna

1 Pojęcie wprowadzone przez Marca Prensky'ego (2001).

2 To dobry kierunek zmian szkolnej polonistyki. Od kilkunastu lat systematycznie wzrasta liczba proponowanych rozwiązań metodycznych z wykorzystaniem technologii informacyjno-komunikacyjnych (zwłaszcza w odniesieniu do analizy i interpretacji klasycznych tekstów literackich oraz innych tekstów kultury). Proponowana obudowa metodyczna podręczników języka polskiego zawiera liczne propozycje zastosowania multimediów podczas pracy z tekstem (Ratajczak i in. 2019). Tego typu działania propagują doradcy metodyczni i pracownicy ośrodków doskonalenia nauczycieli w trakcie różnych kursów i szkoleń. Istnieje również wiele artykułów w prasie polonistycznej adresowanej do nauczycieli języka polskiego (Holajda 2010: 20-25; Kiełczewska 2011: 6-9; Książek-Szczepanikowa 2010: 6-11; Wobalis 2010: 12-18). 
także z gimnazjum). Nauczycielom zależy na terminowym „przerobieniu” materiału, natomiast młodzieży na tym, aby jak najłatwiej przetrwać w szkolnej ławce na języku polskim. W związku z tym zarówno nauczyciele, jak i uczniowie zgadzają się na „pozorność” lekcji:

Poloniści nauczyli się prowadzić lekcje bez oczekiwania, że ktoś w klasie przeczyta lekturę. Uczniowie przyzwyczaili się, że nikt nie będzie miał wobec nich takich oczekiwań. Pytanie tylko, po co w takim razie lekcje literatury. (Janus-Sitarz 2016)

Jak pisze Stanisław Bortnowski, wszyscy zgadzają się na pozory: czytanie bryków i oglądanie adaptacji filmowych. Nauczyciele przystosowali się już do nieczytających uczniów i przygotowują lekcje w ten sposób, by przebiegały w miarę normalnie mimo nieznajomości lektury. (Cieloch-Niewiadomska 2015: 61)

Istnieje kilka powodów takiego stanu rzeczy: pragmatyzm związany z brakiem czasu (niektórzy nauczyciele koncentrują się tylko na przygotowaniu do egzaminu maturalnego), konieczność omawiania narzuconych odgórnie, mało interesujących dla młodzieży lektur szkolnych oraz brak nawyków czytelniczych wśród uczniów. Należy również wspomnieć o zmianach neuronowych w strukturach mózgowych młodego pokolenia, które spowodowała „obecna eksplozja technologii cyfrowej" (Żylińska 2013: 166).

Dzisiejsi piętnastolatkowie zasadniczo różnią się od swoich rówieśników wychowanych w czasach poprzedzających rewolucję informatyczną. Zdaniem Prensky'ego nauczyciele nie zostali przygotowani do pracy z takimi uczniami, jacy dziś siedzą w szkolnych ławkach. Ich przygotowanie pedagogiczne dotyczyło osób, które myślały i uczyły się w sposób daleko odbiegający od tego, jak funkcjonują dzisiejsi uczniowie. I nie chodzi tu o różnice, które w naturalny sposób występują między kolejnymi generacjami. (tamże: 166-167)

Nie ulega wątpliwości, że potrzeba nowej „kultury uczenia się” (Morbitzer 2015: 8-18), w której będą wykorzystywane nowoczesne technologie. Poza tym do rozwiązania pozostaje zagadnienie związane z wykształceniem wśród młodych ludzi umiejętności rozumienia i interpretacji czytanego tekstu. Jak wynika z badań, „młodzież lepiej radzi sobie z czytaniem ze zrozumieniem treści obrazowych niż słownych, co również nie pozostaje bez znaczenia dla współczesnej edukacji [...]" (Wasylewicz i Czopek 2016: 37). Sytuacja nauczyciela w tak nakreślonej rzeczywistości jest trudna. Można powiedzieć, że polonista to 
współczesny Syzyf lub Don Kichot, którego praca pozostaje bez spektakularnych efektów. Jak pisze Anna Janus-Sitarz:

Nauczyciele poloniści z coraz większą bezradnością patrzą na swych wychowanków. Coraz bardziej zniechęceni z rozgoryczeniem rozpoczynają lekcje polskiego, które od dawna przestały być spotkaniami z literaturą, a coraz częściej przypominają przyspieszone kursy przygotowujące do egzaminów. Ich obecni uczniowie to pokolenie, z którym często nie znajdują wspólnego języka: wychowane przed komputerem, pragmatyczne, przedsiębiorcze, przyzwyczajone do niezwykle szybkiego tempa życia, odrzucające wszystko, co wymaga skupienia, systematyczności i dłuższej pracy. (Janus-Sitarz 2011: 273)

Stąd potrzeba dyskusji, nowych propozycji dydaktycznych oraz korzystania z doświadczeń innych, w tym z zagranicznych rozwiązań (Ślósarz 2018: 53-65; Wojtowicz 2001:586-591). Istnieje wyraźna różnica, jeśli chodzi o rozwój dziecka między ośmioletnią szkołą podstawową a czteroletnim liceum lub pięcioletnim technikum. Na wyższym etapie edukacji nastolatkowie już potrafią określić swoje preferencje czytelnicze.

Nie jest prawdą, że młodzi ludzie w ogóle nie czytają. Istnieje liczna grupa uczniów czytających głównie dla przyjemności. Są też takie osoby, które poznają tylko lektury, bo nie mają czasu na inne książki. Niestety, znaczny odsetek populacji wśród młodzieży stanowią osoby, które w ogóle nie mają kontaktu z tekstami literackimi. Aby przetrwać w szkole, korzystają z opracowań, streszczeń i ściąg. Należy zrozumieć, że nie wszyscy młodzi ludzie interesują się literaturą, sztuką i językiem. Nie czują się humanistami i nie marzą o studiach filologicznych. Wielu uczniów poświęca czas na naukę innych przedmiotów, w tym matematyki, biologii czy chemii, aby dostać się na wymarzone studia (jak np. informatyka, medycyna). Ubolewanie nad stanem czytelnictwa dzisiejszej młodzieży nie powinno się wiązać z narzucaniem obowiązku czytania, a raczej z uświadamianiem, jak bardzo znaczący wpływ na rozwój osobowości ma ten proces. Stąd wydaje się, że obecny system omawiania lektur na lekcjach nie sprzyja procesowi polubienia czytania. Młodzi ludzie są obciążeni wieloma obowiązkami i nadmiarem materiału, dlatego chcąc sobie poradzić w szkole, korzystają ze streszczeń i opracowań.

\section{METODA MMT}

W tak ukształtowanej rzeczywistości trudno ustalić, jaki byłby najlepszy, najbardziej efektywny sposób edukacji w dzisiejszej szkole. Już od lat 90. odchodzi się w edukacji od kształcenia historycznoliterackiego (Chrząstowska 2009) 
na rzecz podkreślania wartości samego tekstu. To zarówno tekst literacki, jak i tekst kultury. Według A. Ślósarz:

Wskazane wydaje się zatem opracowanie modułowego programu nauczania, który uwzględniałby środowisko cyfrowe: „parateksty” i konteksty, precyzyjnie dobrane do celów kształcenia, tematyki lektur i zainteresowań uczniów. Reorganizacja zajęć na rzecz bloków tematycznych umożliwia bowiem precyzyjne zaplanowanie kształcenia tak, aby dobierając metody i uzupełniając słabiej opanowane treści, nauczyciel nie tracił z pola widzenia głównego celu nauczania i tekstów w należytej edycji. (Ślósarz 2017: 75)

Proponowana metoda nauczania, nazwana metodą multimedialnych modułów tematycznych (MMT) (Ślósarz 2018), polega na łączeniu głośno odczytanego (w całości lub w dużych fragmentach) tekstu literackiego np. z powiązanym z nim tematycznie filmem lub spektaklem teatralnym. Program ten zakłada nauczanie metodą modułów, w skład których wchodzą: epika, liryka, dramat, malarstwo, multimedia i kształcenie językowe. Zadaniem różnorodnych kontekstów jest aktualizacja i pogłębianie rozumienia literackiego utworu poznanego jako pierwszy i zestawianie jego aksjologii z przedstawioną w powiązanych z nim tematycznie kontekstach. Moduły te mogą być konstruowane przez nauczyciela i uczniów z różnych tekstów, w zależności od potrzeb. W metodzie MMT założono prymat czytania nad omawianiem problematyki, języka bohaterów, świata przedstawionego itp., co wynika z przeznaczenia na lekcji dużej ilości czasu na głośne czytanie utworów literackich, przeżywanie ich i rozmowę o nich. Modułowy program nauczania wiąże zatem dwie tendencje metodycznej refleksji:

[...] jedna dotyczy sposobu istnienia lektury na lekcjach, druga natomiast - treści kształcenia. Pierwsza ma na celu promocję czytelnictwa. [...] [jej nowość] polega na zwróceniu uwagi nauczycieli nie tylko na sam proces poznawania utworu, ale przede wszystkim na umiejętne jego inicjowanie, na motywowanie do podjęcia lektury i tworzenie czytelniczych nawyków. Z kolei drugą tendencję można było kiedyś, jednak na wyrost, nazwać dyskursem niejako rebelianckim, czyli wprowadzaniem literatury „na plecach” innych sztuk, mediów. (Rusek 2017: 20-21)

Zagadnienie celowości łączenia tekstu literackiego z innym tekstem kultury (filmowym, teatralnym, internetowym) pozostaje w kręgu zainteresowań wielu badaczy. Jest to interesujące zagadnienie, na temat którego powstaje wiele publikacji (Bobiński 2011, 2016; Bodzioch-Bryła, Pietruszewska-Kobiela i Regiewicz 2015; Fatyga 2010; Karwatowska i Jarosz 2015; Ogonowska 2005: 79-94; Rajewicz 
2009: 58-61; Regiewicz 2006; Skowronek 2008: 13-17; Ślósarz 2002, 2008). Więcej zwolenników ma pierwsza tendencja, która kładzie szczególny nacisk na wartość czytania samego w sobie. Jak twierdzą sojusznicy tej metody, przynosi ona wiele korzyści i daje bardzo dobre efekty. Szczególnie ważne przemyślenia wiążą się z badaniem skutków, jakie niesie za sobą fakt nieczytania przez uczniów lektur oraz przemilczanie tego zjawiska przez polonistów. Można przypuszczać, że wielu z nich nie zdaje sobie sprawy, jak daleko idące konsekwencje w rozumieniu lektury i świata niesie za sobą zgadzanie się na pozory:

Niestety, za nieprzeczytaną lekturą i zapoznaniem się ze schematami streszczeń i omówień idą uproszczone sądy, zachwianie ocen etycznych, niepokojące wartościowanie. Przykładowo uczniowie, którzy nie przeczytali powieści, piszą o Ziembiewiczu: „[...] prowadził najciekawsze życie. Miał dwie kobiety. Jego życie jest pełne wielu wątków erotycznych”; „[...] miał rozmaite techniki uwodzenia kobiet i bardzo ciekawe życie towarzyskie. Podrywał kobiety i nie znał granic w swoim postępowaniu. Czerpał radość z życia". Natomiast tak oceniają Bogutównę: „nieprzewidywalna”, „niebezpieczna wariatka”. A zatem poświęcanie kilku lekcji na omawianie nieprzeczytanej lektury pociąga za sobą niepokojące konsekwencje, nie tylko bowiem umacnia uczniów w przekonaniu, że czytanie jest zbędne, ale też pozwala im na rozwijanie prymitywnej, uproszczonej wizji świata i drugiego człowieka, oducza empatii oraz rozumienia postaw i motywacji innych ludzi. Cały zatem wysiłek polonisty musi być dzisiaj skierowany na zmotywowanie podopiecznych do czytania. (Janus-Sitarz 2016: 60-61)

Jak wskazują badania, wielu uczniów wypowiada się negatywnie na temat lektur szkolnych, bo ich nie czytają. Są znudzeni książką, zanim ją otworzą. Nie chcą "tracić czasu" na czytanie, męczy ich myślenie na tematy, które ich nie interesują (a trudno znaleźć ciekawy dla nich temat czy zagadnienie). Jednym ze sposobów rozwiązania takiego problemu jest czytanie tekstów na lekcji. Najważniejsze w tej koncepcji jest wejście $\mathrm{w}$ dialog $\mathrm{z}$ tekstem, zadawanie mu pytań i tym samym pogłębianie interpretacji na etapie wspólnego czytania, a następnie podczas porównywania dogłębnie poznanego utworu z innymi, poruszającymi ten sam lub podobny temat. 


\section{GŁOŚNE CZYTANIE KRÓLA EDYPA NA LEKCJI JĘZYKA POLSKIEGO³}

W dniu 12 października 2018 roku przeprowadzono trzy lekcje w klasie I Technikum Hotelarskiego, podczas których uczniowie głośno czytali trudną dla nich poznawczo i językowo lekturę pt. Król Edyp Sofoklesa. Wcześniej chętne osoby zgłosiły się do poszczególnych ról i miały czas, aby się przygotować. W czytaniu lektury wzięło udział 28 uczniów (trzy osoby były nieobecne). Po tygodniu, na jednej z kolejnych lekcji języka polskiego - 19 października 2018 $\mathrm{roku}^{4}$, poproszono uczniów o pisemne odpowiedzi na cztery pytania:

1. Czy czytanie na lekcji Króla Edypa pomogło ci w napisaniu sprawdzianu z lektury? Jeśli tak, to w jakiej mierze, w jaki sposób?

2. Jakie emocje, uczucia towarzyszyły ci podczas czytania lektury na lekcji?

3. Czy według ciebie głośne czytanie tekstów z podziałem na role podczas lekcji ma sens? Uzasadnij swój sąd.

4. Jakie ogólne refleksje na temat życia i losu człowieka możesz wywnioskować, sformułować po lekturze Króla Edypa Sofoklesa?

Na pytanie pierwsze zdecydowana większość uczniów (tj. 22 osoby, 88\% badanych) udzieliła odpowiedzi twierdzącej. Oto niektóre uzasadnienia:

Ponieważ słuchając moich koleżanek i kolegów z klasy mogłam bardziej wczuć się w historię tej książki. (Zuzanna)

Z natury, jeśli chodzi o lektury szkolne, mnie nudzą, lecz poprzez formę czytania na lekcji był to ciekawy sposób przedstawiania książki. (Emilia)

Odróżniłam kto co powiedział w lekturze i bardziej zapamiętałam, o co chodziło w tekście. (Gabriela)

[...] dużo wyniosłam informacji. (Daria)

[...] pomogło mi w rozumieniu tekstu - co się dzieje, kto się wypowiada. (Łukasz)

3 Warto wspomnieć, że można poddać praktycznemu czytaniu w klasie również inne lektury z kanonu, zwłaszcza dramaty (np. Makbet Williama Szekspira, Dziady Adama Mickiewicza). Trzeba się zastanowić, czy lektura fragmentów dłuższych wypowiedzi literackich będzie reprezentatywna dla całości utworu. Czy wybrane fragmenty (np. Lalki Bolesława Prusa, Przedwiośnia Stefana Żeromskiego) mogą zastąpić lekturę całości? Autorka prowadzi badania na ten temat.

4 W tym dniu było obecnych 29 uczniów. Spośród nich trzy osoby były nieobecne podczas "Czytania lektury", dodatkowo jedna osoba nie udzieliła odpowiedzi na trzy pierwsze pytania, w związku z tym przyjęto liczbę 25 jako 100\% respondentów. 
Treść lektury była dla mnie przejrzysta pod takim względem, że mogłam sobie wyobrazić. (Martyna)

[...] ponieważ w głowie wyobrażałam sobie całą akcję oraz pamiętałam bohaterów lektury poprzez kolegów/koleżanki z klasy, którzy czytali. (Weronika)

[...] bardziej zrozumiałam, o co tak naprawdę chodzi w tej książce. (Klaudia)

Lubię słuchać czytane teksty przez innych. (Gabriela)

Gdy czytałam książkę sama, zlewała się ona w jedno i kilkukrotnie musiałam wracać do jakiegoś fragmentu, by upewnić się, kto co powiedział. Przy głośnym czytaniu nie miałam tego problemu, ponieważ od razu pamiętałam kim kto jest i co powiedział. Dzięki temu nie myliłam się na sprawdzianie, np. tego, co Edyp powiedział Tyrezjaszowi, a co Tyrezjasz Edypowi. (Weronika)

Dwie osoby odpowiedziały, że czytanie w niczym im nie pomogło. Jedna osoba stwierdziła, że „troszkę" jej pomogło, „jednak bardziej pomocne jest przerabianie losu Edypa na lekcji, czytanie opracowania oraz szukanie informacji w Internecie" (Natalia). Podsumowując, na pytanie, czy głośne czytanie lektury pomogło ci w napisaniu sprawdzianu z jej treści: $88 \%$ respondentów udzieliło odpowiedzi twierdzącej; $8 \%$ odpowiedziało, że nie; $4 \%$ uczniów nie udzieliło jednoznacznej odpowiedzi. Młodzi ludzie, uzasadniając swój pogląd, zwrócili uwagę przede wszystkim na możliwość wyobrażenia sobie bohaterów oraz akcji lektury, co sprzyjało lepszemu zrozumieniu tekstu. Podkreślili też możliwość jej przeżywania (Zuzanna), większe zainteresowanie (Emilia) i kojarzenie kwestii z bohaterami (Weronika).

Drugie pytanie dotyczyło emocji wyzwalanych w młodych ludziach podczas głośnego czytania. Aż 21 uczniów (ponieważ dwie osoby nie udzieliły odpowiedzi na to pytanie), wskazało na następujące emocje ${ }^{5}$ :

- ciekawość i zainteresowanie lekturą: 12 osób (48\%),

- skupienie, koncentracja, próba zapamiętywania: 5 osób (20\%),

- zaskoczenie losami bohatera: 2 osoby ( $8 \%)$,

- zdziwienie językiem: 2 osoby (8\%),

- „bezsilność w związku z historią Edypa”: 1 osoba (4\%),

- „wczucie się": 1 osoba (4\%),

- zmęczenie: 1 osoba (4\%),

- znudzenie, „ciekawie, choć czasem nudno”: 1 osoba (4\%).

5 Niektóre emocje powtarzały się kilkakrotnie u różnych uczniów. 
Z powyższego zestawienia wynika, że 21 uczniów, czyli 84\% klasy, podczas głośnego czytania lektury odczuwało emocje pozytywne. Tylko dwóch uczniów wskazało na zmęczenie i znudzenie, przy czym z ich wypowiedzi wynika, że były to emocje chwilowe. Na uwagę zasługują ciekawe uzasadnienia:

Uczucia to na pewno zaskoczenie treścią lektury. Zwracałam dużą uwagę na język, który dużo odchodził od naszego współczesnego. (Martyna)

Towarzyszyła mi ciekawość, co okaże się na końcu, towarzyszył mi smutek podczas ostatnich stron lektury. (Klaudia)

Dwie osoby (8\%; te same, które w pierwszym pytaniu udzieliły odpowiedzi negatywnej) wskazały na znudzenie, brak zrozumienia oraz brak skupienia podczas czytania.

Trzecie pytanie dotyczyło opinii co do zasadności czytania lektury na lekcji. Aż 22 osoby ( $88 \%$ ankietowanych uczniów) udzieliły na to pytanie odpowiedzi twierdzącej. Oto niektóre ciekawsze uzasadnienia:

Tak, uważam, że takie czytanie ma sens, ponieważ my sami (głównie osoby czytające) musimy w pewnym sensie wczuć się w rolę, aby w jak najlepszy sposób przekazać to innym słuchaczom oraz mamy mniej do przeczytania w domu. (Amelia)

Ma sens, gdyż nie wszyscy mają warunki, by w spokoju przeczytać lekturę, a poza tym mi lepiej było sobie wyobrazić i wczuć się w treść lektury. Przez podział na role pamiętamy bohaterów lektury, gdyż utożsamiamy z nimi kolegów oraz koleżanki z klasy. Dzięki temu łatwiej zobrazować sobie daną akcję. (Weronika)

Myślę, że czytanie na głos lektur ma sens. Zawsze daje to Pani satysfakcję, że klasa przeczytała lekturę i jedynie musi powtórzyć informacje, a więc sprawdzian pójdzie dobrze. Czytanie na lekcji to też integracja, która działa na nas dobrze. (Gabriela)

Uważam, że takie czytanie ma sens, ponieważ na bieżąco można zadać pytania Pani, jeśli się czegoś nie rozumie oraz osoby, które nie czytają będą zmuszone do osłuchania się z tekstem. (Natalia)

Analizując odpowiedzi uczniów, należy stwierdzić, że większość z nich uważa, iż głośne czytanie lektury na lekcji ma sens, ponieważ:

- pomaga w zrozumieniu tekstu: 8 osób (32\%), 
- można zapamiętać dużo informacji: 6 osób (24\%),

- można się „wczuć”: 4 osoby (16\%),

- nie przeczytaliby tej lektury w domu: 3 osoby (12\%),

- można sobie wyobrazić akcję: 2 osoby $(8 \%)$,

- integracja klasy: 1 osoba (4\%),

- jak się czegoś nie rozumie, to można zadać pytanie Pani: 1 osoba (4\%).

Trzy uczennice odpowiedziały, że głośne czytanie na lekcji nie ma sensu. Dwie z nich to te same osoby, które w poprzednich pytaniach zdecydowanie opowiedziały się przeciw takim formom lekcji. Uzasadniły to w następujący sposób:

Według mnie nie ma sensu, ponieważ każdy inaczej czyta, na czym innym się skupia, musi przeczytać kilka rzeczy, by zrozumieć tekst, a w taki sposób nie może przeczytać sobie jeszcze raz od razu. Poza tym w taki sposób marnuje się lekcje, ponieważ większość osób prawdopodobnie nie uważała i/lub nie mogła się skupić. Niektórzy wolą czytać po cichu (np. ja) i głośne czytanie przeszkadza w skupieniu się. (Julia)

Nie ma sensu, ponieważ większość nie słucha i nie skupia się, gdy ktoś czyta. (Aleksandra)

Trzecia osoba miała zastrzeżenia co do długości tekstów czytanych na lekcji:

Czytanie tekstów z podziałem na role jest bardzo dobre, lecz przy krótkich tekstach, ponieważ przy dłuższych wypowiedziach się nudzimy i nie słuchamy. (Natalia)

Były to jednak głosy odosobnione. Aby zapobiec nudzeniu się takich uczniów, nauczyciel może zaplanować dla nich nadobowiązkowe zadania, polegające np. na zaprojektowaniu kostiumów i scenografii, zrecenzowaniu występów do szkolnej gazetki, przeczytaniu opracowania, nauczeniu się fragmentu na pamięć itp.

Ostatnie pytanie dotyczyło zrozumienia i przeżycia lektury. Odpowiadając na nie, uczniowie wskazali na fakt, że:

- człowiek nie jest w stanie przewidzieć swojego losu,

- człowiek nie ma wpływu na swoje życie,

- każdy ponosi klęskę w walce z przeznaczeniem,

- życie człowieka wiąże się z cierpieniem,

- życie człowieka jest nieprzewidywalne,

- szczęście jest ulotne, nic nie trwa wiecznie.

We wszystkich odpowiedziach uczniów pojawiły się powyższe stwierdzenia. Refleksje te wynikają z przekonania, że to przeznaczenie i nieznany los czy Bóg rządzą ludzkim życiem. 
Podsumowując wyniki ankiety, należy podkreślić, że przeważająca większość klasy oceniła pozytywnie głośne czytanie lektury z podziałem na role. Swoje stanowisko uczniowie argumentowali w sposób logiczny i przemyślany, wskazując na różne aspekty lekcji. Dotyczyły one zarówno sfery metodycznej (ciekawa lekcja), jak i osobistej (utożsamianie się z bohaterami), praktycznej (łatwiejsze zapamiętywanie) i psychologicznej (integracja klasy).

\section{PORÓWNANIE PRAC PISEMNYCH PO (NIE)CZYTANIU LEKTURY}

Po kilkunastu tygodniach (15.02.2019) uczniowie tej samej klasy napisali wypracowanie na temat, w którym mogli odwołać się do Króla Edypa Sofoklesa. Temat zadania brzmiał następująco: „Rozum - siła człowieka czy źródło pychy prowadzącej do klęski? Rozważ problem, analizując podany fragment ${ }^{6}$ i odwołując się do wybranego dramatu antycznego oraz innego tekstu kultury. Twoja praca powinna liczyć co najmniej 250 wyrazów".

Porównano prace klasy czytającej na głos Króla Edypa podczas lekcji (klasa IH - Technikum Hotelarskie) z pracami uczniów, którzy nie czytali lektury na lekcji. Obie klasy napisały wypracowania na ten sam temat. Klasa, która czytała lekturę w domu (klasa 1B - Liceum Ogólnokształcące - profil matematyczny) napisała wypracowanie rok wcześniej (24.04.2018). Obie klasy po przeczytaniu (nieprzeczytaniu) lektury omówiły ją w ten sam sposób ${ }^{7}$, z tym samym nauczycielem, według scenariuszy lekcji zaproponowanych przez to samo wydawnictwo podręcznika do języka polskiego ${ }^{8}$.

6 Sofokles, Antygona - „CHÓR: Siła jest dziwów, lecz nad wszystkie sięga / Dziwy człowieka potęga. / Bo on prze śmiało poza sine morze, / Gdy toń się wzdyma i kłębi. / I z roku na rok swym lemieszem porze / Matkę ziemicę do głębi. / Lotny ród ptaków i stepu zwierzęta / I dzieci fali usidla on w pęta, / Wszystko rozumem zwycięży. / Dzikiego zwierza z gór ściągnie na błonie, / Krnąbrny kark tura i grzywiaste konie / Ujarzmi w swojej uprzęży. / Wynalazł mowę i myśli dal skrzydła / I życie ujął w porządku prawidła, / Od mroźnych wichrów na deszcze i gromy / Zbudował sobie schroniska i domy, / Na wszystko z radą on gotów. / Lecz choćby śmiało patrzał w wiek daleki. / Choć ma na bóle i cierpienia leki. / Śmierci nie ujdzie on grotów. / A sił potęgę, które w duszy tleją, / Popchnie on zbrodni lub cnoty koleją; / [...] CHÓR: Nad szczęścia błysk, co złudą mar, / Najwyższy skarb rozumu dar. / A wyzwie ten niechybny sąd, / Kto bogów lży i wali rząd. / I ześlą oni swą zemstę i kary / Na pychę słowa w człowieku, / I w klęsk odmęcie rozumu i miary / W późnym nauczą go wieku".

7 Warto zaznaczyć, że łącznie na przeczytanie lektury i jej omówienie poświęcono sześć godzin lekcyjnych.

8 Por. Scenariusze lekcji WSiP do podręczników (Chemperek, Kalbarczyk i Trześniowski 2014: 197-217). Tematy: „Tragedia grecka - bohater tragiczny i jego tragizm”, „Koncepcja losu ludzkiego w tragedii antycznej”, „Fatum i wina w tragedii greckiej”, „Porozumienie i nieporozumienie w języku”, „Religijny charakter Króla Edypa”. 
Hipoteza badawcza była następująca: Uczniowie ze zdolnej, matematycznej klasy Liceum Ogólnokształcącego częściej odwoływali się do lektury i przedstawili ją w sposób bardziej pogłębiony niż uczniowie Technikum Hotelarskiego.

Prace zestawiono i porównano według dwóch kryteriów:

1) liczba uczniów, którzy odwołali się w wypracowaniu do tragedii Król Edyp,

2) liczba uczniów, którzy pogłębili interpretację lektury, uzasadniając swoje stanowisko.

Za pogłębienie interpretacji uznano: dłuższą wypowiedź (ponad cztery zdania), w tym co najmniej cztery z następujących elementów: nawiązanie do treści Króla Edypa, przywołanie mitu o rodzie Labdakidów, wymienienie innych bohaterów (np. Kreon, Jokasta, Lajos, Sfinks); zwrócenie uwagi na tragizm bohatera, wskazanie jego cech; próbę osądu i oceny bohatera bądź sytuacji, w której się znalazł; brak błędów rzeczowych. Oto przykład takiej wypowiedzi:

Król Edyp również tego samego autora ukazuje nam trudności z jakimi zmierzył się główny bohater. Nad jego losem ciążyło fatum, któremu mężczyzna próbował się sprzeciwić. Na początku lektury nie wiedział o swoim przeznaczeniu lecz $\mathrm{w}$ trakcie dalszych wydarzeń, wbrew swoim zamierzeniom, powoli odkrywał okrutną prawdę. Rozum pozwolił Edypowi na drastyczne kroki, których się podjął, ale uważał je za słuszne. Prośba Kreona o wygnanie go z miasta oraz wydłubanie sobie oczu to jedne z licznych działań mężczyzny. Nie mógł się on pogodzić z losem lecz sądził, że Teby nie mogą mieć takiego króla jakim był on sam. Edyp poważnie przemyślał wszystkie kroki a rozum pozwolił mu na podjęcie ostatecznych decyzji. (Emilia)

Przez brak pogłębienia interpretacji rozumiano krótką wypowiedź (mniej niż cztery zdania), ogólnikowe stwierdzenia na temat głównego bohatera, możliwość wystąpienia błędu rzeczowego lub kardynalnego, np.:

Natomiast przykładem osoby, której rozum okazał się siłą był Edyp z dramatu Sofoklesa pod tytułem Król Edyp, gdzie rozum pomaga Edypowi dojść do władzy przy okazji pomagając mieszkańcom Koryntu, a także okazuje się dobrym władcą. Lecz przez ciążące nad nim fatum poznaje prawdę o sobie i skazuje siebie na wygnanie. (Jakub) 
Pobrane z czasopisma Annales N - Educatio Nova http://educatio.annales.umes.pl Data: 26/04/2023 14:18:22

Tabela 1. Wyniki porównania

\begin{tabular}{|l|c|c|c|}
\hline & \multicolumn{2}{|c|}{$\begin{array}{c}\text { Uczniowie czytający } \\
\text { głośno na lekcji }\end{array}$} & $\begin{array}{c}\text { Uczniowie } \\
\text { czytający w domu }\end{array}$ \\
\hline Liczba prac & 28 & $100,00 \%$ & 35 \\
\hline $\begin{array}{l}\text { Liczba uczniów, którzy odwołali } \\
\text { się do lektury Król Edyp }\end{array}$ & 15 & $53,57 \%$ & 16 \\
\hline $\begin{array}{l}\text { Liczba uczniów, którzy pogłębili } \\
\text { interpretację lektury }\end{array}$ & 9 & $32,14 \%$ & 8 \\
\hline
\end{tabular}

Źródło: opracowanie własne.

Z zestawienia wyników prac uczniowskich wynika, że hipoteza się nie potwierdziła, ponieważ więcej uczniów (procentowo) odwołało się do antycznego dramatu Król Edyp w klasie z Technikum, która czytała ten tekst głośno na lekcji. Również więcej osób z tej klasy pogłębiło interpretację lektury. Jest to zaskakujące, gdyż klasa z Liceum Ogólnokształcącego osiąga lepsze wyniki w nauce (ma wyższą średnią ocen oraz wyższą średnią frekwencję) niż klasa z Technikum. W związku z tym można założyć, że głośne czytanie na lekcji przyniosło pozytywne efekty. Uczniowie potrafili przywołać odpowiedni tekst oraz pogłębić jego interpretację. Zwrócili uwagę na rozterki Edypa i lepiej zrozumieli okoliczności, jakie towarzyszyły jego decyzjom.

\section{WNIOSKI: KONKURUJACE PRZEKAZY MEDIALNE JAKO AKSJOLOGICZNE WYZWANIE DLA EDUKACJI}

Przedstawione badania odnoszą się do pierwszego elementu metody MMT, którym jest poznawanie tekstu na lekcji przez jego wspólne, głośne odczytanie oraz przeżywanie. Czy czytanie podczas lekcji to strata czasu? Odpowiedź jest oczywista - czytanie samo w sobie jest niezastąpioną wartością. Dzięki procesowi czytania młody człowiek kształtuje swoją osobowość, rozwija się oraz lepiej rozumie i wartościuje świat. Dzięki czytaniu może odkryć kim jest, skąd pochodzi i dokąd zmierza, co jest w życiu rzeczywiście ważne i warte wysiłku. To czytanie uwrażliwia go na innych oraz na jego własne potrzeby.

Opisane badania to początek dalszych eksploracji tego zagadnienia, koniecznych w dobie konkurujących z literaturą atrakcyjnych przekazów medialnych (jak np. streszczenia, ściągi, filmowe adaptacje). Tylko rzetelnie poznany i przeżyty na lekcji tekst literacki ma szansę zachować swą poznawczą i aksjologiczną integralność w obliczu ich ekspansji. Stąd postulat wspólnego czytania na lekcji wydaje się w pełni uzasadniony.

Natomiast problematyka wpływu otoczenia medialnego na aksjologię zaprezentowaną w szkolnych lekturach (jak we wspomnianym przypadku o Królu 
Edypie) wymaga dalszych badań i kompleksowych działań przy zastosowaniu adekwatnych metod nauczania, np. ukierunkowującej rozumienie wybranego problemu aksjologicznego metody multimedialnych modułów tematycznych, która polega na celowym zestawianiu tekstu literackiego i np. multimediów w postaci filmu, gry, teledysku, ujawniających i uzmysławiających uczniom przesunięcia znaczeniowe i aksjologiczne zachodzące w kulturowym otoczeniu szkolnych lektur.

\section{BIBLIOGRAFIA}

\section{Literatura}

Bobiński, W. (2011). Teksty w lustrze ekranu. Okotofilmowa strategia ksztatcenia literacko-kulturowego. Kraków: TAiWPN Universitas.

Bobiński, W. (2016). Wyksztatcić widza. Sztuka ogladania w edukacji polonistycznej. Kraków: TAiWPN Universitas.

Bodzioch-Bryła, B., Pietruszewska-Kobiela, G., Regiewicz, A. (2015). Literatura nowe media. Homo irretitus w kulturze literackiej XX $i$ XXI wieku. Częstochowa: Wydawnictwo im. Stanisława Podobińskiego.

Bortnowski, S. (2007). Kanon literacki: między potrzebą a buntem. W: A. Janus-Sitarz (red.), Szkolne spotkania z literatura (s. 15-28). Kraków: TAiWPN Universitas.

Chemperek, D., Kalbarczyk, A., Trześniowski, D. (2014). Nowe. Zrozumieć tekst-zrozumieć człowieka. Starożytność-średniowiecze. Ksztatcenie w zakresie podstawowym i rozszerzonym. Podręcznik do jezzka polskiego dla liceum i technikum, klasa 1. Cz. 1. Warszawa: WSiP.

Chrząstowska, B. (2009). Jak uczyć rozumienia historyczności w nowym liceum. W: tejże, Przedmiot, podmiot i proces. Szkice z metodyki ksztatcenia polonistycznego (s. 163172). Poznań: Poznańskie Studia Polonistyczne.

Cieloch-Niewiadomska, J. (2015). Szkoła nieczytania. www.nck.pl/upload/archiwum_ $\mathrm{kw}$ _files/artykuly/4._joanna_cieloch-niewiadomska_-_szkola_nieczytania.pdf [dostęp: 25.01.2019].

Dyrda, T., Gumuła, T. (2009). Wybrane problemy edukacji szkolnej w Polsce. W: T. Dyrda, T. Gumuła (red.), Szkoty, nauczyciele, uczniowie: dyskusja o programie, metodzie, uczeniu się w Europie (s. 33-55). Radom: Wydawnictwo Naukowe Instytutu Technologii Eksploatacji - PIB.

Fatyga, A. (2010). Literatura i ekran, czyli spotkania z filmem na lekcjach jezyka polskiego. Kraków: Wydawnictwo Edukacyjne.

Holajda, D.K. (2010). E-biblioteki w kształceniu polonistycznym. Polonistyka, nr 11, $20-25$.

Janus-Sitarz, A. (2009). Kryzys lektury na tle innych kryzysów cywilizacyjnych. W: tejże, Przyjemność i odpowiedzialność w lekturze. O praktykach czytania literatury w szkole (s. 27-96). Kraków: TAiWPN Universitas. 
Janus-Sitarz, A. (2011). Najpierw trzeba chcieć czytać. Studenci zachęcają licealistów do lektury. W: A. Janus-Sitarz (red.), Szkolna lektura bliżej teraźniejszości (s. 273-286). Kraków: TAiWPN Universitas.

Janus-Sitarz, A. (2016). W poszukiwaniu czytelnika: diagnozy, inspiracje, rekomendacje. Kraków: Universitas. Pobrane z: www.cbeiku.polonistyka.uj.edu.pl/documents/85721075/eef43f25-e9cc-460a-879d-130fe2de086d [dostęp: 4.04.2019].

Kania, A., Strawa-Kęsek, E. (2015). Innowacyjne praktyki studenckie jako profesjonalizacja zawodu i szansa na rynku pracy. W: Janus-Sitarz (red.), Twórcze praktyki polonistyczne (s. 187-199). Kraków: Universitas. Pobrane z: www.cbeiku.polonistyka. uj.edu.pl/documents/85721075/815d863d-9c05-4baa-a035-213af5230b53 [dostęp: 4.04.2019].

Kaniewski, J. (2007). Kanon a przestrzeń kulturowa ucznia. W: tegoż, Koncepcja egzaminu maturalnego a kształcenie polonistyczne (s. 267-309). Poznań: Wydawnictwo Naukowe Uniwersytetu im. Adama Mickiewicza.

Karwatowska, M., Jarosz, B. (2015). (Nowe) media. Implikacje kulturowe, językowe i edukacyjne. Lublin: Wydawnictwo UMCS.

Kiełczewska, S. (2011). Muzea w sieci. Polonistyka, nr 11, 6-9.

Książek-Szczepanikowa, A. (2010). Hipertekst w multimediach - zbliżenie. Polonistyka, nr 11, 6-11.

Morawska, I. (2017). Kanon lektur szkolnych. Krytyka i obrona. W: I. Morawska, M. Latoch-Zielińska (red.), Edukacja polonistyczna wobec przemian kulturowych (s. 29-44). Lublin: Wydawnictwo UMCS.

Morbitzer, J. (2015). Nowa kultura uczenia się - ku lepszej edukacji w cyfrowym świecie. Nowa Szkoła, nr 2, 8-18.

Ogonowska, A. (2005). Problematyka edukacji medialnej w kontekście wybranych zagadnień pedagogiki krytycznej. Kwartalnik Pedagogiczny, nr 1, 79-94.

Prensky, M. (2001). Digital Natives, Digital Immigrants. Pobrane z: www.marcprensky. com/writing/Prensky\%20-\%20Digital\%20Natives,\%20Digital\%20Immigrants\%20 -\%20Part1.pdf [dostęp: 30.01.2019].

Rajewicz, D. (2009). Edukacja przez film. Polonistyka, nr 3, 58-61.

Ratajczak, C., Prylińska, E., Manthey, J., Budna, K., Zieliński, T., ..., Zaporowicz, J. (2019). Jezyk polski. Sztuka wyrazu. Podręcznik do 1 klasy liceum i technikum. Zakres podstawowy i rozszerzony. Gdańsk: Gdańskie Wydawnictwo Oświatowe.

Regiewicz, A. (2006). Dialog filmu z literatura. Scenariusze lekcji dla liceum i technikum. Gdańsk: Gdańskie Wydawnictwo Oświatowe.

Rusek, M. (2017). Bitwa książek i bitwa o książki. Transformacje kształcenia literackiego. W: I. Morawska, M. Latoch-Zielińska (red.), Edukacja polonistyczna wobec przemian kulturowych (s. 13-27). Lublin: Wydawnictwo UMCS.

Skowronek, B. (2008). Jak filmoznawca może pomóc szkolnemu poloniście w interpretowaniu tekstów kultury. Polonistyka, nr 2, 13-17.

Ślósarz, A. (2002). Lektury licealne a kino komercyjne. Kraków: Wydawnictwo i Poligrafia Zakonu Pijarów.

Ślósarz, A. (2008). Media w stużbie polonisty. Kraków: Wydawnictwo Naukowe Akademii Pedagogicznej. 
Ślósarz, A. (2017). Lektury szkolne po remediacji druku. W: I. Morawska, M. Latoch-Zielińska (red.), Edukacja polonistyczna wobec przemian kulturowych (s. 59-76). Lublin: Wydawnictwo UMCS.

Ślósarz, A. (2018). Interpretanty lektur. Produkty medialnego przemystu. Multimedialne moduty tematyczne jako dydaktyczny instrument. Kraków: Wydawnictwo Naukowe Uniwersytetu Pedagogicznego.

Wasylewicz, M., Czopek, J. (2016). Miejsce i rola internetu i mediów społecznościowych w przestrzeni edukacyjnej. Nowa Szkoła, nr 4, 31-39.

Wobalis, M. (2010). E-rzeczywistość czy e-nierzeczywistość? Polonistyka, nr 11, 12-18.

Wojtowicz, A. (2001). Jak Anglicy uczą czytania. Polonistyka, nr 10, 586-591.

Żylińska, M. (2013). Neurodydaktyka. Nauczanie i uczenie się przyjazne mózgowi. Toruń: Wydawnictwo Naukowe Uniwersytetu Mikołaja Kopernika.

\section{Akty prawne}

Rozporządzenie Ministra Edukacji Narodowej z dnia 30 stycznia 2018 roku w sprawie podstawy programowej kształcenia ogólnego dla liceum ogólnokształcącego, technikum oraz branżowej szkoły II stopnia (Dz.U. 2018, poz. 467). 